\title{
Hand hygiene compliance in a tertiary university hospital
}

\author{
Kathrin Pepper ${ }^{1 *}$, Hermine Hörhan ${ }^{1}$, Cornelia Jeuschnigger ${ }^{1}$, Christine Prietl ${ }^{1}$, Claudia Höfer ${ }^{1}$, Brigitte Kober ${ }^{2}$, \\ Renate Zierler', Gerald Sendlhofer ${ }^{2,3}$ \\ From Safety in hospitals: from strategy to implementation Annual Scientific Meeting 2015 \\ Graz, Austria. 29-30 September 2015
}

\section{Background}

Health care-associated infections (HAI) are a major patient safety issue worldwide and several reports found that improved hand hygiene $(\mathrm{HH})$ was associated with reduced HAI [1]. Reasons for low adherence to $\mathrm{HH}$ are diverse [2] and the Joint Commission set the targeted goal for $\mathrm{HH}$ compliance to achieve > 90\% [1].

In 2012 the University Hospital Graz initiated the campaign "Clean Hands" and paid particular attention to improving healthcare professionals' knowledge of the WHO's My Five Moments for HH [3]. The main components of the campaign comprised training, distribution of posters and provision of materials encouraging patients and relatives to clean their hands. In 2013 and 2014 direct observations to assess HH compliance took part [1]. The aim of this study was to assess the compliance of $\mathrm{HH}$ within professional groups in three different environments.

\section{Material and methods}

In total, 23 units (wards and intensive care units) were informed that direct observations will be performed by trained hygiene experts for the WHO's My Five Moments for Hand Hygiene model. Results are shown for a non-surgical ICU, surgical ICU and pediatric ward.

Phase 1 - baseline direct observation: Baseline direct observation took place and for each indication at least 20 direct observations had to be performed. The overall compliance was calculated when more than 150 direct observations in a unit had been performed. At the end of the direct observation feedback was given by hygiene experts.

* Correspondence: kathrin.pepper@klinikum-graz.at

'Department of Surgery, University Hospital Graz, Graz, Austria

Full list of author information is available at the end of the article
Phase 2 - follow up direct observation: Each unit was given the opportunity to reflect their habits according to the baseline results. After 6 to 12 months, a follow up observation was performed and again feedback was given.

\section{Results}

In a non-surgical ICU, the overall compliance rate increased from $53 \%$ to $83 \%$, in a surgical ICU from $68 \%$ to $82 \%$ and in a pediatric ward from $85 \%$ to $91 \%$ (Table 1 ).

Compliance rates for all professional groups increased over time and were highest within "others" (Table 2).

\section{Conclusions}

$\mathrm{HH}$ is considered to be the most important measure to prevent nosocomial infections [4] and results of direct observations show that $\mathrm{HH}$ motivation can be addressed with comprehensive $\mathrm{HH}$ campaigns. Overall, improvements in the $\mathrm{HH}$ behavior were achieved for all indications and had been near or even above to the Joint Commission recommendation. The compliance rate for the professional group "others" showed the highest increase.

\section{Competing interests}

The authors declare that they have no competing interests.

\section{Acknowledgements}

We would like to thank the entire organization and their employees for supporting the HH-campaign. We also would like to thank "National Reference Centre for the Surveillance of Nosocomial Infections" (www.nrz-hygiene.de) for data analysis.

\section{Authors' details \\ 'Department of Surgery, University Hospital Graz, Graz, Austria. ${ }^{2}$ Department of Quality and Risk Management, University Hospital Graz, Graz, Austria. ${ }^{3}$ Division of Plastic, Aesthetic and Reconstructive Surgery, Department of Surgery, Medical University of Graz, Graz, Austria.}


Table 1. Compliance results in selected units (*less than 20 observations)

\begin{tabular}{|c|c|c|c|}
\hline Indication & Observations (n) & Hand hygiene (n) & Compliance (\%) \\
\hline \multicolumn{4}{|l|}{ 1) Before patient contact } \\
\hline Baseline (nonsurgical ICU) & 48 & 23 & 48 \\
\hline Follow up (nonsurgical ICU) & 57 & 49 & 86 \\
\hline Baseline (surgical ICU) & 52 & 33 & 63 \\
\hline Follow up (surgical ICU) & 55 & 50 & 91 \\
\hline Baseline (ward) & 66 & 52 & 79 \\
\hline Follow up (ward) & 47 & 38 & 81 \\
\hline \multicolumn{4}{|l|}{ 2) Before aseptic task } \\
\hline Baseline (nonsurgical ICU) & 29 & 13 & 45 \\
\hline Follow up (nonsurgical ICU) & 30 & 26 & 87 \\
\hline Baseline (surgical ICU) & 30 & 18 & 60 \\
\hline Follow up (surgical ICU) & 31 & 18 & 58 \\
\hline Baseline (ward) & 25 & 19 & 76 \\
\hline Follow up (ward) & 20 & 18 & 90 \\
\hline \multicolumn{4}{|l|}{ 3) After body fluid exposure risk } \\
\hline Baseline (nonsurgical ICU) & 24 & 19 & 79 \\
\hline Follow up (nonsurgical ICU) & 33 & 28 & 85 \\
\hline Baseline (surgical ICU) & 28 & 24 & 86 \\
\hline Follow up (surgical ICU) & 30 & 28 & 93 \\
\hline Baseline (ward) & 12 & 12 & $-*$ \\
\hline Follow up (ward) & 22 & 22 & 100 \\
\hline \multicolumn{4}{|l|}{ 4) After patient contact } \\
\hline Baseline (nonsurgical ICU) & 74 & 46 & 62 \\
\hline Follow up (nonsurgical ICU) & 61 & 56 & 92 \\
\hline Baseline (surgical ICU) & 69 & 49 & 71 \\
\hline Follow up (surgical ICU) & 66 & 58 & 88 \\
\hline Baseline (ward) & 68 & 60 & 88 \\
\hline Follow up (ward) & 58 & 54 & 93 \\
\hline \multicolumn{4}{|l|}{ 5) After contact with patient surroundings } \\
\hline Baseline (nonsurgical ICU) & 53 & 20 & 38 \\
\hline Follow up (nonsurgical ICU) & 25 & 13 & 52 \\
\hline Baseline (surgical ICU) & 21 & 12 & 57 \\
\hline Follow up (surgical ICU) & 22 & 14 & 64 \\
\hline Baseline (ward) & 50 & 44 & 88 \\
\hline Follow up (ward) & 32 & 30 & 94 \\
\hline
\end{tabular}

Table 2. Compliance results in selected cohorts (\%)

\begin{tabular}{lccc}
\hline & Physician & Nurses & Others \\
\hline Baseline (nonsurgical ICU) & 43 & 56 & 39 \\
\hline Follow up (nonsurgical ICU) & 54 & 88 & 79 \\
\hline Baseline (surgical ICU) & 34 & 79 & 58 \\
\hline Follow up (surgical ICU) & 39 & 90 & 96 \\
\hline Baseline (ward) & 87 & 90 & 29 \\
\hline Follow up (ward) & 84 & 99 & 48 \\
\hline
\end{tabular}




\section{References}

1. Boyce JM: Update on hand hygiene. Am J Infect Control 2013, 41(5 Suppl): S94-S96.

2. Boyce JM, Pittet D: Healthcare Infection Control Practices Advisory Committee; HICPAC/SHEA/APIC/IDSA Hand Hygiene Task Force. Guideline for hand hygiene in health-care settings. Recommendations of the Healthcare Infection Control Practices Advisory Committee and the HICPAC/SHEA/APIC/IDSA Hand Hygiene Task Force. Am J Infect Control 2002, 30(8):S1-46.

3. World Health Organization. Patient Safety. WHO Guidelines on Hand Hygiene in Health Care. First global patient safety challenge clean care is safer care 2009 [http://www.who.int/gpsc/5may/en/], (accessed 30 August 2014).

4. Erasmus V, Daha TJ, Brug H, et al: Systematic review of studies on compliance with hand hygiene guidelines in hospital care. Infect Control Hosp Epidemiol 2010, 31: 283-294.

doi:10.1186/2056-5917-1-S1-A13

Cite this article as: Pepper et al.: Hand hygiene compliance in a tertiary university hospital. Safety in Health 2015 1(Suppl 1):A13.

\section{Submit your next manuscript to BioMed Central} and take full advantage of:

- Convenient online submission

- Thorough peer review

- No space constraints or color figure charges

- Immediate publication on acceptance

- Inclusion in PubMed, CAS, Scopus and Google Scholar

- Research which is freely available for redistribution

Submit your manuscript at www.biomedcentral.com/submit 